\title{
Contrasting Effects of Ionic Liquids of Varying Degree of Hydrophilicity on the Conformational and Interfacial Properties of a Globular Protein
}

\author{
Krishna Prasad Ghanta, Souvik Mondal, Sandip Mondal, and Sanjoy
}

$$
\text { Bandyopadhyay* }
$$

Molecular Modeling Laboratory, Department of Chemistry, Indian Institute of Technology, Kharagpur - 721302, India

E-mail: sanjoy@chem.iitkgp.ac.in 


\section{Supporting Information}

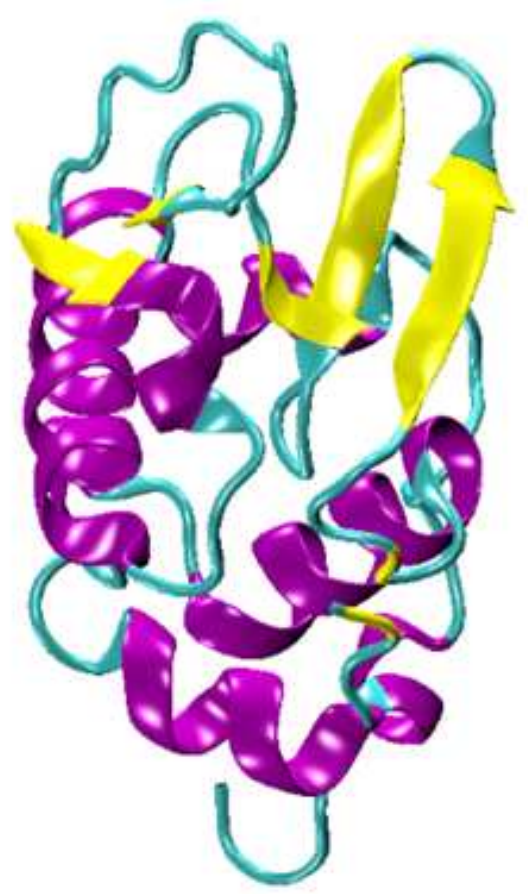

Figure SI-1: The structure of the 123-residue protein $\alpha$-lactalbumin as obtained from high resolution x-ray diffraction study. ${ }^{1}$ The secondary structures of the protein consist of three $\alpha$-helices, two $3_{10}$ helices, and one antiparallel $\beta$-sheet comprising of two $\beta$-strands. The helices are drawn in purple, the $\beta$-strands in yellow and the interconnecting turn/coil segments in cyan. The amino acid residue sequence of the protein in one-letter code is K(1)QLTKCALSHELNDLAGYRDITLPEWLCIIFHISGYDTQAIVKNSDHKEYGLFQIND KDFCESSTTVQSRNICDISCDKLLDDDLTDDIMCVKKILDIKGIDYWLAHKPLCSDKLE QWYCEAQ(123) 

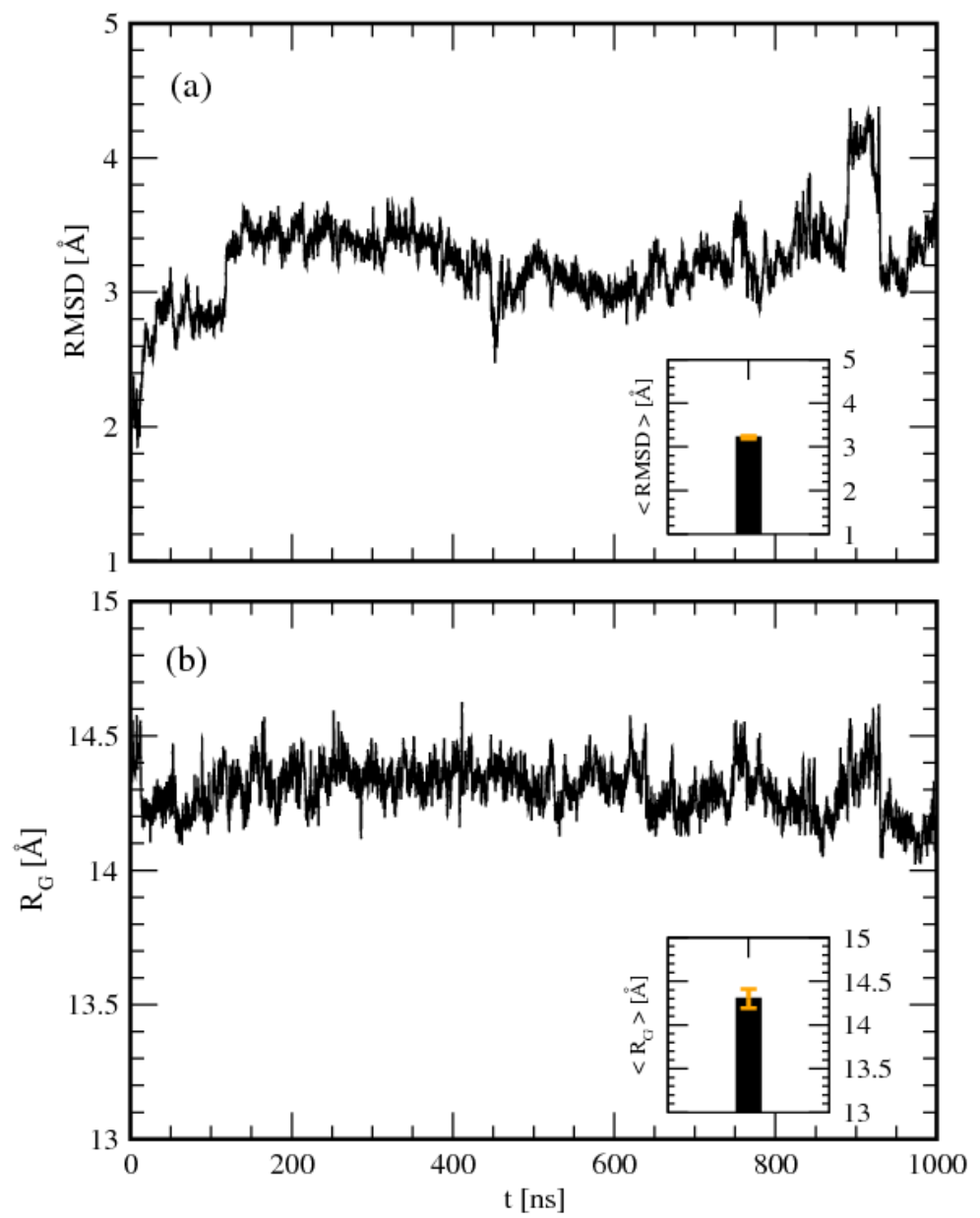

Figure SI-2: Time evolutions and the average values of (a) RMSD and (b) $\mathrm{R}_{G}$ of the protein $\alpha$-lactalbumin in pure water. 


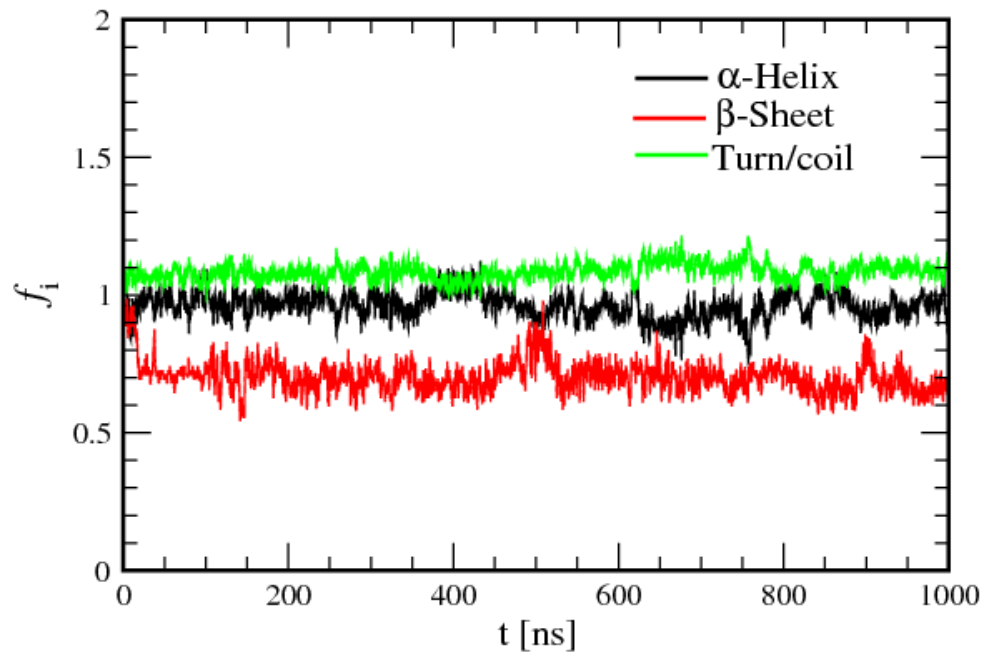

Figure SI-3: Time evolutions of the fractions $\left(f_{i}\right)$ of $\alpha$-helical, $\beta$-sheet and turn/coil contents of the protein $\alpha$-lactalbumin in pure water. 

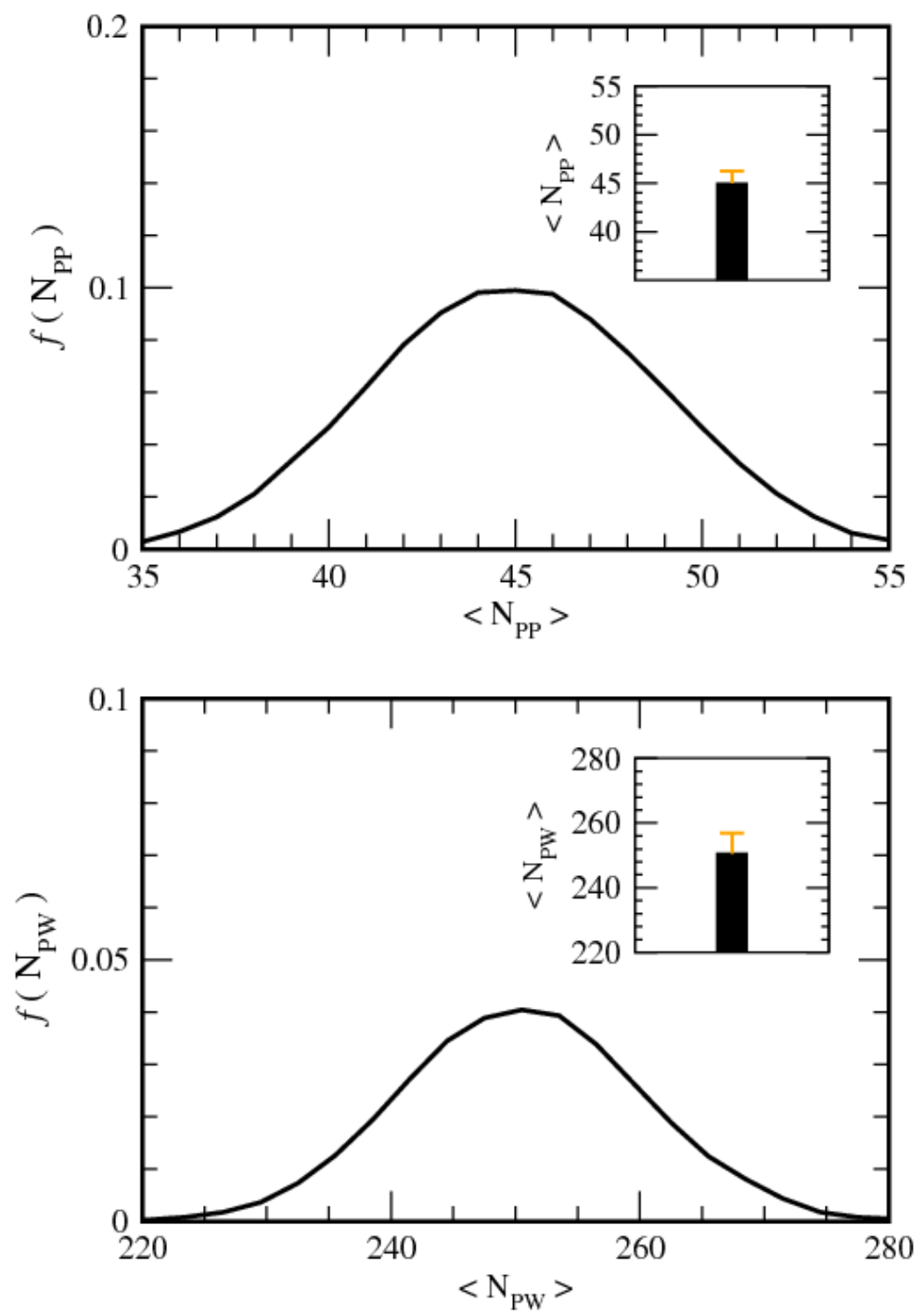

Figure SI-4: Distributions of the numbers of protein-protein and protein-water hydrogen bonds $\left(N_{P P}, N_{P W}\right)$ and the corresponding average values for the protein $\alpha$-lactalbumin in pure water. 


\section{References}

(1) Pike, A. C.; Brew, K.; Acharya, K. R. Crystal Structures of Guinea-Pig, Goat and Bovine $\alpha$-Lactalbumin Highlight the Enhanced Conformational Flexibility of Regions that are Significant for its Action in Lactose Synthase. Structure 1996, 4, 691-703. 